\title{
Dynamics of Dissolved Organic Carbon in Forested and Disturbed Catchments, Westland, New Zealand 2. Larry River
}

\author{
T. R. MOORE \\ Department of Geography, McGill University, Montreal, Quebec, Canada \\ R. J. JACKSON \\ Forest Research Institute, Ministry of Forestry, Christchurch, New Zealand
}

\begin{abstract}
Dissolved organic carbon (DOC) dynamics were investigated in three small wetland catchments: one covered by a scrub forest and the other two cleared, V-bladed, and planted with pine, 1 and 4 years before sampling. Over a 4-month sampling period, DOC concentrations averaged 1.4, 20.9, 47.1, 46.0, and $45.7 \mathrm{mg} / \mathrm{L}$ in precipitation, throughfall, stemflow, surface soil water, and subsoil water, respectively, in the scrub forest catchment. DOC concentration in the stream draining the catchment averaged $43.4 \mathrm{mg} / \mathrm{L}$, reflecting the inability of the Larry River subsoils to adsorb DOC and the pathways taken by water. In 1986, discharge-weighted DOC concentrations in the streams ranged from $29.9 \mathrm{mg} / \mathrm{L}$ in the catchment disturbed 4 years before sampling to $35.0 \mathrm{mg} / \mathrm{L}$ in the recently disturbed catchment and $37.9 \mathrm{mg} / \mathrm{L}$ in the catchment covered by scrub forest. DOC export from the catchments in 1986 was estimated to be $30.6,43.8$, and $41.7 \mathrm{~g} \mathrm{~m}^{-2} \mathrm{yr}^{-1}$, suggestıng that disturbance had a minor effect on DOC export. The role of the high DOC concentrations on the chemistry of the stream water was revealed by a large anion deficit, an average anion deficit:DOC relationship of $5.7 \mathrm{meg} / \mathrm{g}$, and an annual export of acidity of $184-263 \mathrm{meq} \mathrm{m}^{-2} \mathrm{yr}^{-1}$. Within-storm sampling showed that $\mathrm{pH}$ and DOC were related inversely and base titration suggested acid dissociation constants $\left(p \mathrm{~K}_{\mathrm{a}}\right)$ ranging from 4.4 to 4.9 .
\end{abstract}

\section{INTRODUCTION}

Streams draining forested catchments with well-drained soils usually contain low concentrations of dissolved organic carbon (DOC), in the range 1-12 mg/L [e.g., Clair and Freedman, 1986; Foster and Grieve, 1982; Hobbie and Likens, 1973; Meyer and Tate, 1983; Moore, this issue; Tate and Meyer, 1983]. Where wetlands, such as swamps and bogs, cover a significant portion of the catchment area, DOC concentrations are much higher, generally in the range 10-40 mg/L [e.g., Freedman and Clair, 1987; Kerekes et al., 1986; McKnight et al., 1985; Moore, 1987a, b, c; Mulholland, 1981; Mulholland and Kuenzler, 1979; Schlesinger and Melack, 1981].

The elevated concentrations of DOC in wetland streams can influence water chemistry through complexation of metals [e.g., Reuter and Perdue, 1977], absorption of light [e.g., Davies-Colley and Vant, 1987], and production of carcinogenic compounds when treated with chlorine [e.g., Oliver and Thurman, 1983]. Moreover, high concentrations of DOC can influence the acidity of the water, as has been shown by Eshleman and Hemond [1985], Gjessing [1976], Gorham et al. [1985], McKnight et al. [1985], Oliver et al. [1983], and Thurman [1985]. In areas subject to acid precipitation, studies have apportioned the acidity to organic or anthropogenic sources [e.g., Kerekes et al., 1986].

Several studies have examined the influence of disturbance, such as forest clear-cutting, on the concentrations and fluxes of DOC in well-drained catchments [see Moore, this issue]. In a study of bogs in southern Quebec, Moore

Copyright 1989 by the American Geophysical Union.

Paper number $89 \mathrm{WR} 00344$ 0043-1397/89/89WR-00344\$05.00 [1987b] observed only minor changes in stream DOC concentrations in drained and harvested bogs, compared to the undisturbed set of peatlands.

In the present paper, we examine the concentration and fluxes of DOC in three small wetland catchments near Larry River. The catchments are characteristic of "pakihi" land, extensive throughout much of the South Island of New Zealand [Mew, 1983]. One of the catchments has been left in undisturbed manuka scrub forest, whereas the other two catchments have been drained and planted with pine. We examine the major controls and influence of vegetation, soil, and hydrology and catchment disturbance on DOC concentrations and fluxes and the role that DOC plays in the acidity of the stream water.

\section{STudy Site}

The three Larry River catchments were established by the New Zealand Forest Service near Reefton, North Westland, South Island, New Zealand $\left(42^{\circ} 05^{\prime} \mathrm{S}, 171^{\circ} 48^{\prime} \mathrm{E}\right)$. They occur on the highest of a series of fluvioglacial terraces at an elevation of about $300 \mathrm{~m}$, with only minor relief $(<3 \mathrm{~m})$ within the small (about $10 \mathrm{ha}$ ) catchments. The soils are Aquic Spodosols and Histosols, comprised of $0.1-0.4 \mathrm{~m}$ of peaty topsoil overlying $0.4 \mathrm{~m}$ of massive, grey, silt loam subsoil, and underlain by glacial outwash gravels [Ross et al., 1977]. The soils often have an iron and/or humus pan close to the surface, which lowers permeability [Jackson, 1984; Mew and Lee, 1981]. The catchments were covered originally by beech-podocarp forest, but were logged and cleared for farming in the 19th century. Poor drainage and low fertility caused a reversion to moss/fern/scrub vegetation, dominated by manuka (Leptospermum scoparium) and mosses (Sphagnum). The mean annual precipitation is about 
TABLE 1. Characteristics of the Three Experimental Catchments at Larry River

\begin{tabular}{|c|c|c|}
\hline Catchment & $\begin{array}{c}\text { Area, } \\
\text { ha }\end{array}$ & Treatment \\
\hline Ll & 10.0 & $\begin{array}{l}\text { Manuka scrub, crushed October 1981; } \\
\text { burned March 1982; V-bladed, } \\
\text { fertilized and planted with pine } \\
\text { April-June } 1982\end{array}$ \\
\hline L2 & 11.6 & undisturbed manuka scrub \\
\hline L3 & 9.9 & $\begin{array}{l}\text { Manuka scrub, crushed October 1984; } \\
\text { burned February 1985; V-bladed } \\
\text { February 1985; fertilized and } \\
\text { planted with pine August } 1985\end{array}$ \\
\hline
\end{tabular}

$2500 \mathrm{~mm}$, which produces approximately $1500 \mathrm{~mm}$ of runoff in each catchment [Jackson, 1987].

One catchment (L2) has been left in undisturbed manuka scrub forest, regenerating after a fire about 40 years earlier (Table 1). The other two catchments ( L1 and L3) have had the vegetation crushed and burned and the soil V-bladed to a depth of $0.3-0.4 \mathrm{~m}$ to expose the subsoil and the topsoil has been moved into ridges $0.5 \mathrm{~m}$ high and $1.5-2 \mathrm{~m}$ wide. Parallel runs were made with the $\mathrm{V}$ blade, about $8 \mathrm{~m}$ apart, leaving a $2-m$ strip of undisturbed ground between the ridges. Radiata pine (Pinus radiata) was planted on the ridges. The L1 catchment (in which $32 \%$ of the catchment was left as manuka scrub, in the headwaters) was treated and planted in 1982 and the pines were $3-5 \mathrm{~m}$ tall in 1986. By 1986, the stream channel in L1 had been gradually invaded by rushes and Sphagnum. The L3 catchment was treated and planted in 1985 , with the pines reaching $0.5-1 \mathrm{~m}$ tall in 1986 .

\section{Methods}

\section{Sample Collection}

Precipitation, thoughfall, and stemflow were collected as described previously [Moore, this issue]. Five throughfall funnels and stemflow collars around five manuka trees were placed in the $\mathbf{L} 2$ catchment. Soil water was sampled by evacuating porous ceramic cups at depths of $10-15 \mathrm{~cm}$ (topsoil) and $30-40 \mathrm{~cm}$ (subsoil) in both the L2 and L3 catchments. Samples were collected weekly from February to May 1986.

Samples of stream water draining each catchment were collected from the weir at weekly intervals from January to December 1986 along with discharge at time of sampling. Automatic samplers located at the weir provided water samples collected at 12 hour intervals during storms, especially in the L3 catchment. Stage height was monitored continuously by water level recorders and converted to discharge, runoff, and a flow-duration curve.

\section{Budget Calculations}

DOC export from the catchments was calculated using DOC:discharge relationships and flow duration data for 1986. Discharge was separated into 30 flow classes and the DOC concentration for the middle value calculated from the DOC:discharge regression. The classes were then converted to export from runoff in each of the classes and summed for the period January 1 to December 31, 1986. Dann et al. [1986] have noted that the reliability of ion export calculations is dependent on the methods used. There were strong relationships between DOC and discharge in catchments $\mathrm{Ll}$ and L3, but not in catchment L2; hence the DOC export data should be treated with some caution.

\section{Chemical Analyses}

Water samples were filtered through GF/C paper and analyzed for DOC as described previously [Moore, this issue]. The relationship between DOC and absorbance at 330 $\mathrm{nm}$ was used to predict DOC concentrations from absorbance measurements from the period June to December, 1986 [Moore, 1987d]. The regression used was

$$
\mathrm{DOC}=38.9 \mathrm{abs}+7.6
$$

where DOC is given in milligrams per liter, abs is absorbance at $330 \mathrm{~nm}$ in a $1-\mathrm{cm}$ cell, $n=158, r^{2}=0.88$, and the standard error of the estimate is $2.7 \mathrm{mg} / \mathrm{L}$.

Six samples of stream water, two from the Maimai catchments [Moore, 1989] and four from the Larry River catchments were analyzed for their chemical composition. After filtration through Gelman $0.45 \mu \mathrm{m}$ Metricel GA6 paper, $p \mathrm{H}$ was measured with a $p \mathrm{H}$ meter, $\mathrm{Ca}^{2+}, \mathrm{Mg}^{2+}, \mathrm{Na}^{+}$, and were $\mathrm{K}^{+}$determined by atomic absorption spectrophotometry, $\mathrm{NH}_{4}^{+}$by indophenol [Searle, 1975], and $\mathrm{NO}_{3}^{-}, \mathrm{Cl}^{-}$and $\mathrm{SO}_{4}^{2-}$ by ion chromatography.

A base titration was performed on the six samples to determine acid characteristics, as described by Eshleman and Hemond [1985]. The ionic strength of a $100-\mathrm{mL}$ aliquot was adjusted to $0.1 \mathrm{~N}$ by addition of $0.8 \mathrm{~g}$ of $\mathrm{KCl}$ and acidified to $p \mathrm{H} 3$ by addition of $120 \mu \mathrm{L}$ of $1 \mathrm{~N} \mathrm{HCl}$. The sample was titrated at $25^{\circ} \mathrm{C}$ against $0.05 \mathrm{~N} \mathrm{NaOH}$, being sparged continuously with nitrogen to remove carbon dioxide; sparging was maintained to prevent reaeration. The alkali was added in increments ranging from 0.005 to $0.1 \mathrm{~mL}$, using a syringe; $p \mathrm{H}$ was determined with a Gilmot digital $p \mathrm{H}$ meter to 3 decimal places. The titration raised the $p \mathrm{H}$ from 3.0 to 9.0 , using between 30 and 60 alkali increments. A sample of distilled water was titrated as a standard.

The titration results were used to generate the derivatives ( $m=\left[\mathrm{H}^{+}\right] /\left[\mathrm{OH}^{-}\right]$add) as a function of $p \mathrm{H}$, as described by Eshleman and Hemond [1985]. Graphical and statistical analysis of the m: $\mathrm{H}$ relationships were used to estimate dissociation constants $\left(p \mathrm{~K}_{\mathrm{a}}\right)$ and concentrations of acids in the samples, using the techniques discussed by Lee [1980].

\section{RESULTS}

\section{Concentration and Fluxes of DOC in an Undisturbed Catchment}

DOC concentrations in precipitation averaged $1.4 \mathrm{mg} / \mathrm{L}$, but were much higher in throughfall (average $20.9 \mathrm{mg} / \mathrm{L}$ ) and stemflow $(47.1 \mathrm{mg} / \mathrm{L})$ in the undisturbed manuka scrub in the L2 catchment (Table 2). The surface soil water samples (10-15 cm depth) also contained high concentrations of DOC (average $46.0 \mathrm{mg} / \mathrm{L}$ ), as did the water collected from the subsurface horizons at a depth of $35-40 \mathrm{~cm}$ (average 45.7 $\mathrm{mg} / \mathrm{L}$ ). The stream draining the $\mathrm{L} 2$ catchment also contained high concentrations of DOC (average $43.4 \mathrm{mg} / \mathrm{L}$ ).

The above pattern of changes in DOC concentrations is similar to that observed in the Maimai catchment [Moore, this issue], except that the latter revealed a major decrease in DOC as the water passed through the subsoil and into the stream. As noted previously [Moore, this issue], the Larry 
TABLE 2. A Budget of DOC Fluxes in the Undisturbed Catchment L2, Larry River

\begin{tabular}{lccc}
\hline & $\begin{array}{c}\text { Flux, of } \\
\text { Water, } \\
\mathrm{mm}\end{array}$ & $\begin{array}{c}\text { DOC } \\
\text { Concentration, } \\
\mathrm{mg} / \mathrm{L}\end{array}$ & $\begin{array}{c}\text { DOC } \\
\text { Flux, g C } \\
\mathrm{m}^{-2} \mathrm{yr}^{-1}\end{array}$ \\
\hline Precipitation & 2500 & $\begin{array}{c}1.4 \\
(0.7,19)\end{array}$ & 3.5 \\
Throughfall & 1625 & $\begin{array}{c}20.9 \\
(11.4,34) \\
47.1\end{array}$ & 34.0 \\
Stemflow & 500 & $\begin{array}{c}(32.7,49) \\
46.0\end{array}$ & 23.6 \\
Surface soil water & 1500 & $\begin{array}{c}(8.7,24) \\
45.7\end{array}$ & 69.0 \\
Subsurface soil water & 1500 & $\begin{array}{c}4.3,32) \\
43.4\end{array}$ & 68.6 \\
Stream & 1500 & $(4.8,16)$ & 65.1 \\
\hline
\end{tabular}

Budget was based on measurements of DOC concentrations in precipitation, throughfall, stemflow, surface and subsurface water, and stream water from February to May 1986. Figures in parentheses indicate the standard deviation and number of samples analyzed, respectively. Flux of water for each component is based on an average year and estimated contributions of throughfall, stemflow, and runoff.

River subsoil horizons contain very low amounts of amorphous (oxalate-extractable) iron and aluminum and possess high equilibrium concentrations of DOC $(30-40 \mathrm{mg} / \mathrm{L})$. Thus there is little evidence of DOC adsorption in the subsoils of the Larry River soils and the subsoils tend to have low organic carbon concentrations, except where $\mathrm{Fe}$-Al-organic pans have developed [Ross et al., 1977]. In addition, there is more lateral flow of water in the Larry River catchment, allowing water to reach the stream channel without passing through the subsoil [Jackson, 1987].
Detailed measurements of water flux in the L2 catchment have not been made, but estimates of the average annual hydrologic budget and average DOC concentrations allow the construction of a tentative budget of DOC flux. In a manuka stand at Taita, near Wellington, North Island, Aldridge and Jackson [1968] observed that throughfall and stemflow accounted for 45 and $23 \%$ of the incident precipitation (totalling $807 \mathrm{~mm}$ ), respectively, over a 10-month period. Based on their study and the much higher annual precipitation at Larry River, throughfall and stemflow are estimated to average approximately 1625 and $500 \mathrm{~mm}$, respectively.

Using these values, DOC flux in precipitation is low, about $3.5 \mathrm{~g} \mathrm{~m}^{-2} \mathrm{yr}^{-1}$, but major increases occur in the throughfall and stemflow, reaching about $57 \mathrm{~g} \mathrm{~m}^{-2} \mathrm{yr}^{-1}$ in the soil surface. This increases further to a flux of about $65-70 \mathrm{~g} \mathrm{~m}^{-2}$ $\mathrm{yr}^{-1}$ from the soil and the stream. The above-ground and surface soil fluxes are similar to those reported at the Maimai forest [Moore, this issue]. The higher flux from the subsoils and stream in the Larry River catchment appear to be related to the poorer capacity of Larry River subsoils to adsorb DOC and differences in hydrology, especially the lateral movement of water.

\section{The Influence of Discharge on Stream DOC Concentrations}

DOC concentrations in stream samples collected at weekly intervals from the 3 catchments ranged from 10 to 50 $\mathrm{mg} / \mathrm{L}$ (Figure 1) and were generally highest in the undisturbed L2 catchment and also particularly during summer.

In the undisturbed L2 catchment, there was no significant $(p>0.05$ ) relationship between the log of discharge and

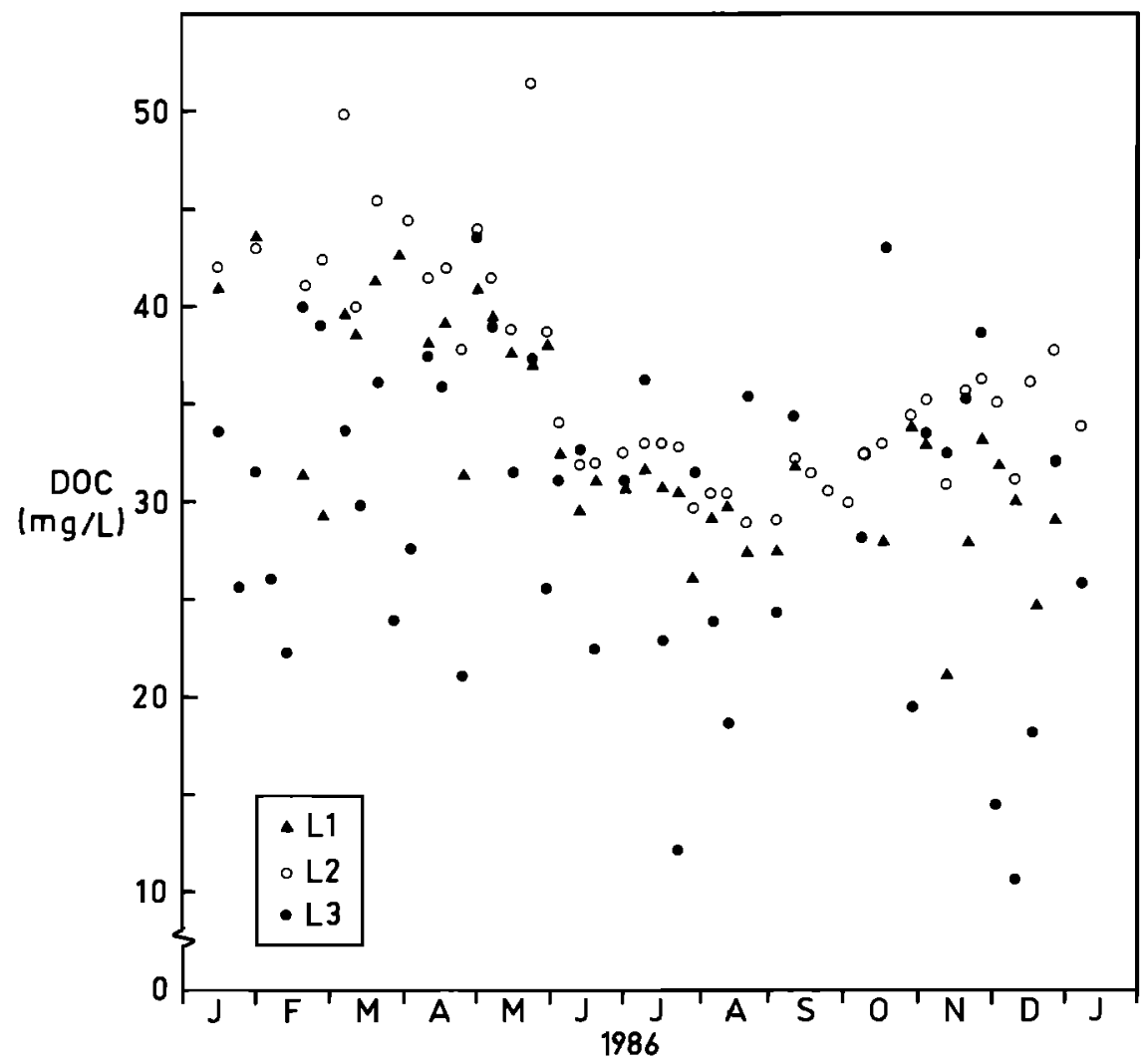

Fig. 1. Weekly DOC concentrations in streams draining catchments L1, L2, and L3. 


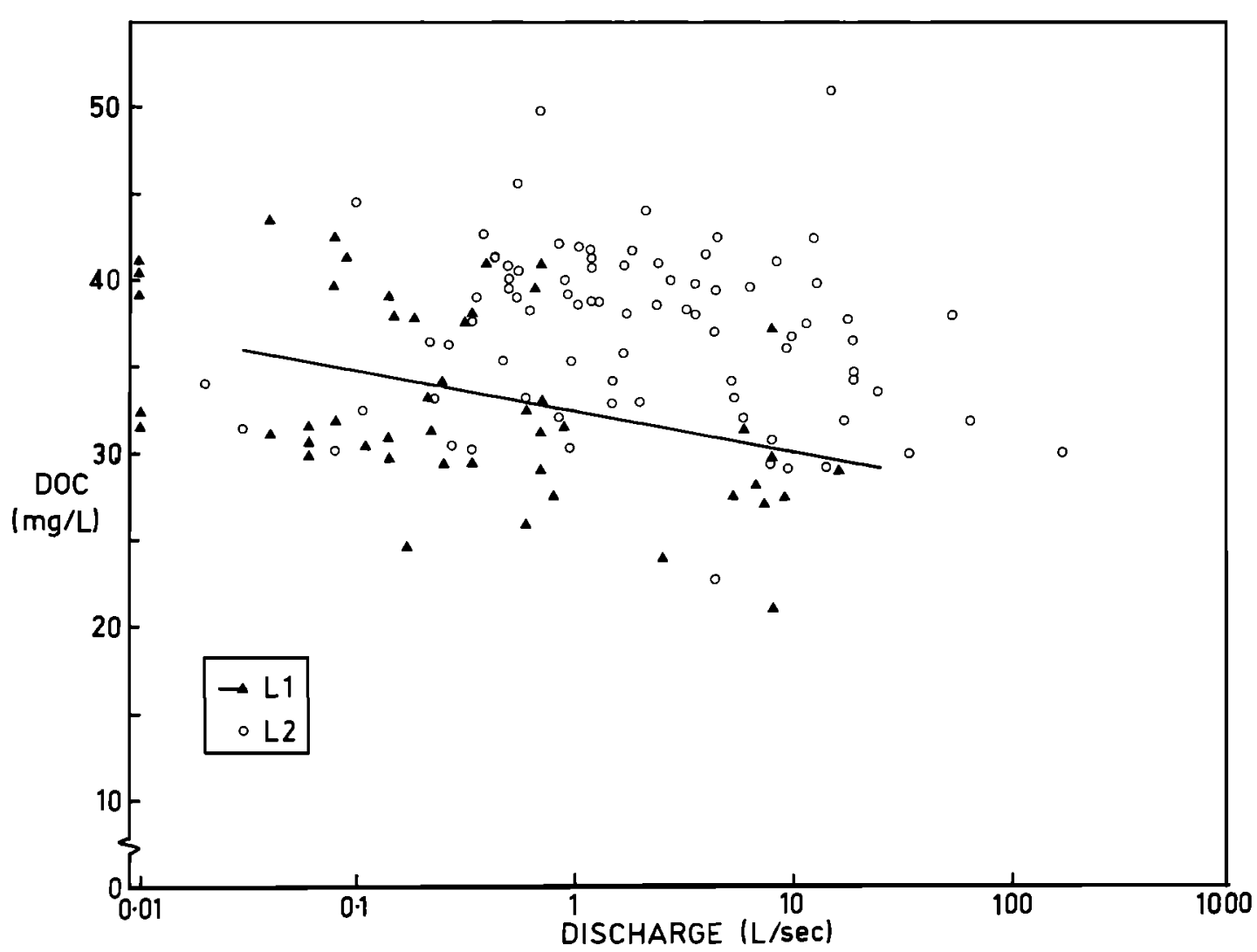

Fig. 2. The relationship between DOC concentration and discharge in the streams draining catchments L1 and L2. The regression line represents the logarithmic relationship defined for $\mathrm{L} 1$ in Table 3 .

DOC concentration (Figure 2 and Table 3). There was, however, a significant $(p<0.05)$ negative relationship at catchment $\mathrm{L} 1$, the catchment disturbed 4 years before sampling (Figure 2 and Table 3).

There was no significant $(p>0.05)$ overall relationship between log discharge and DOC in the stream draining catchment L3, including the samples collected during storms. By splitting the discharge data into sets of $<$ and $>$ $1 \mathrm{~L} / \mathrm{s}$, significant $(p<0.01)$ relationships were found. At low discharges, there was a strong positive relationship with DOC concentration, whereas a negative relationship was found at high discharges (Figure 3 and Table 3).

However, only small proportions of the variation in DOC were predicted from the log of the discharge $\left(r^{2} 0.00-0.50\right)$. Whether the sample was collected on the rising or falling limb of the hydrograph appeared to influence DOC concen- trations, which were generally higher on the falling limb (up to $5 \mathrm{mg} / \mathrm{L}$ ) than on the rising limb, at the same discharge (Figure 4).

This pattern can be explained for catchment L3 as much of the initial rainfall in a storm falls on to exposed subsoils, produced by the $\mathrm{V}$ blading. These subsoils have low permeability and low organic carbon content, thereby producing runoff low in DOC. Toward the middle and end of the storm, the water draining the ridges of displaced topsoil and the undisturbed organic material between the ridges would play a more important role in stream discharge. This water would pass through peaty topsoil picking up large concentrations of DOC (average $40.5 \mathrm{mg} / \mathrm{L}$ ), thereby elevating DOC concentrations in the stream. Infrequent within-storm sampling precludes the establishment of a similar pattern in catchments $\mathrm{L} 1$ and $\mathrm{L} 2$.

TABLE 3. Relationship Between DOC Concentrations and Discharge $Q$ in the Three Larry River Streams and the Estimated Export of DOC and Runoff From the Catchments in 1986

\begin{tabular}{lllcc}
\hline Catchment & \multicolumn{1}{c}{ Relationship } & \multicolumn{1}{c}{$r^{2}$} & $\begin{array}{c}\text { DOC Export, } \\
\mathrm{g} \mathrm{m}^{-2} \mathrm{yr}^{-1}\end{array}$ & $\begin{array}{c}\text { Runoff, } \\
\mathrm{mm}\end{array}$ \\
\hline L1 & DOC $=32.0-1.92 \log Q$ & $0.116^{*}$ & 30.6 & 1023 \\
L2 & DOC $=37.4-1.03 \log Q$ & 0.023 & 41.7 & 1099 \\
L3 overall & DOC $=32.6+0.12 \log Q$ & 0.000 & & \\
L3 $Q<1 \mathrm{~L} / \mathrm{s}$ & DOC $=38.0+7.18 \log Q$ & $0.307 \dagger$ & & \\
L3 $Q>1 \mathrm{~L} / \mathrm{s}$ & DOC $=45.1-8.58 \log Q$ & $0.501 \dagger$ & 43.8 & 1253 \\
\hline
\end{tabular}

DOC concentrations are given in milligrams per liter and discharge $Q$ is given in liters per second. *Significant at $<0.05$.

+ Significant at $<0.001$. 


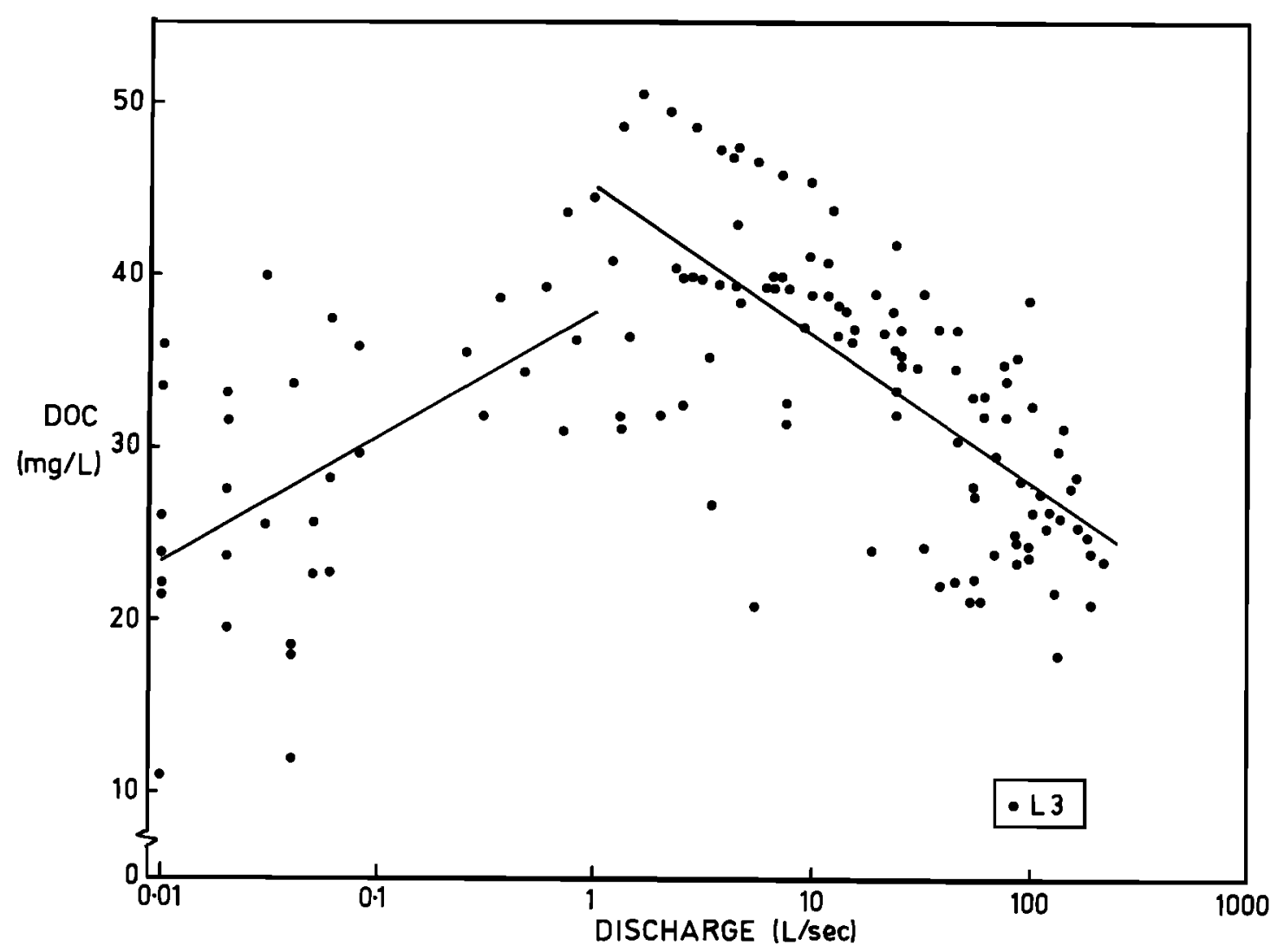

Fig. 3. The relationship between DOC concentration and discharge in the stream draining catchment L3. The regression lines represent the logarithmic relationships defined in Table 3.

The Influence of Disturbance on DOC Concentrations and Export

Ranking of the weekly DOC measurements revealed that the undisturbed L2 catchment had the highest DOC concentrations, followed by the disturbed catchments $\mathrm{L} 1$ and L2 (Table 4). The average DOC concentrations, based on these weekly samples varies from $36.8 \mathrm{mg} / \mathrm{L}$ in the $\mathrm{L} 2$ stream to 32.8 and $30.3 \mathrm{mg} / \mathrm{L}$ in the $\mathrm{L} 1$ and $\mathrm{L} 3$ streams, respectively.
DOC export in 1986 was calculated using DOC:discharge regressions and flow:duration data for the three catchments (Table 3). Estimated export was highest in catchments L2 and L3, the higher discharge-weighted DOC concentrations in $\mathrm{L} 2$ being compensated by higher runoff in $\mathrm{L} 3$. Catchment L1, disturbed 4 years before sampling, had both the lowest export and average discharge-weighted DOC concentration (30.6 $\mathrm{g} \mathrm{m}^{-2} \mathrm{yr}^{-1}$ and $29.9 \mathrm{mg} / \mathrm{L}$, respectively). The above

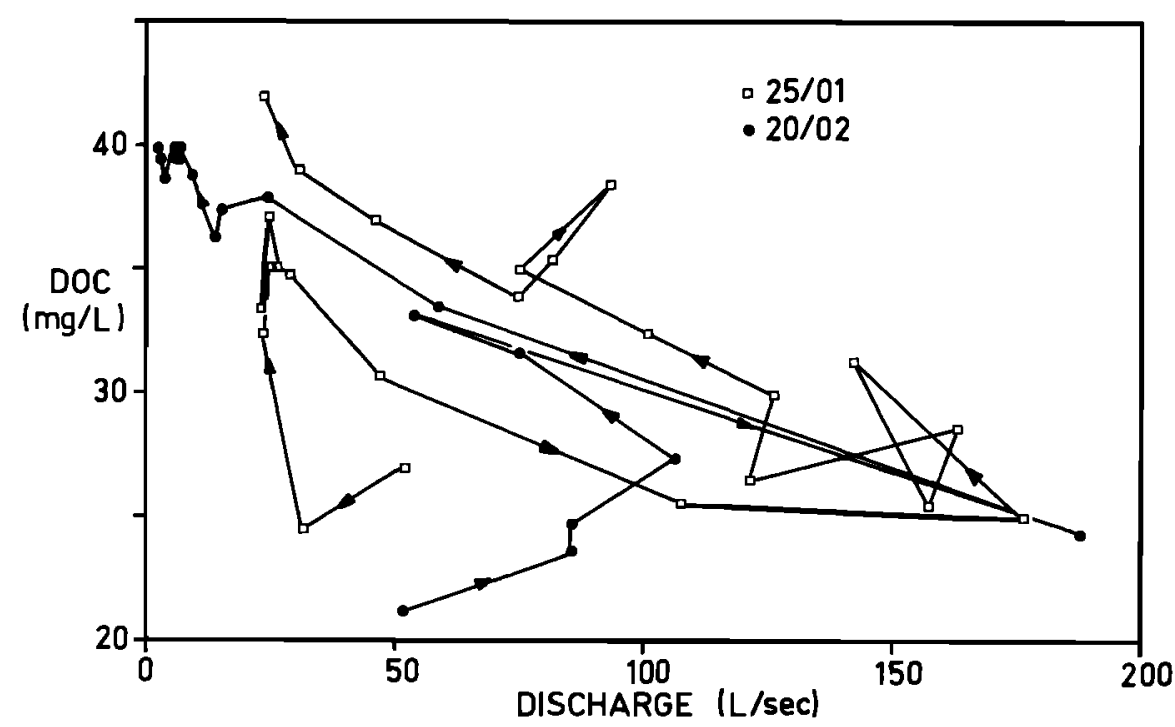

Fig. 4. The variation in DOC concentration in relation to discharge in the stream draining catchment $\mathrm{L} 3$ during two storms on January 25, 1986, and February 20, 1986. Samples were taken at hourly intervals. 
TABLE 4. Average Rank and DOC Concentrations in Streams Draining Catchments L1, L2, and L3, Based on Weekly Sampling During 1986

\begin{tabular}{ccc}
\hline Catchment & Mean Rank & Mean DOC, mg/L \\
\hline L1 & $2.4(0.5)$ & $32.8(5.1)$ \\
L2 & $1.3(0.5)$ & $36.8(5.7)$ \\
L3 & $2.4(0.8)$ & $30.3(8.5)$ \\
\hline
\end{tabular}

Figures in parentheses indicate the standard deviation.

calculations should be treated with some caution because of the weak association between discharge and DOC concentrations, especially in catchment $\mathrm{L} 2$. The results suggest that disturbance of these Larry River catchments initially caused only minor changes in DOC concentration and export, which did not manifest changes until 4 years after disturbance.

\section{The Influence of DOC on Water Acidity}

The streams draining the Larry River catchments are very acid $(p \mathrm{H} 3.7-4.2)$ with the undisturbed catchment $\mathrm{L} 2$ having a $p \mathrm{H}$ about 0.1 to 0.2 units lower than in the disturbed catchments L1 and L3. The high DOC concentrations in the streams may be expected to influence the acidity of the stream and this was examined in two ways.

Relationships between DOC and $p \mathrm{H}$ were examined in samples collected within storms in the L2 and L3 catchments. Rainwater in most storms had a $p H$ ranging from 4.5 to 6.0 , whereas manuka throughfall and stemflow $p H$ values averaged 5.5 and 5.2, respectively. Increases in stream water $p \mathrm{H}$ were associated with decreases in DOC concentrations, with all regressions significant at the $p<0.01$ level (Figure 5 ). The regression coefficients from the storms analyzed ranged from 0.010 to 0.022 , with an average of 0.014 . Thus a decrease in DOC concentration of $10 \mathrm{mg} / \mathrm{L}$ was associated with an increase in $p \mathrm{H}$ of 0.1 to 0.2 units.

The chemical composition of the six stream water samples used for titration revealed DOC concentrations ranging from $5.3 \mathrm{mg} / \mathrm{L}$ in Maimai catchment 6 to $41.7 \mathrm{mg} / \mathrm{L}$ in catchment
L2 (Table 5). Cation:anion ratios ranged from 1.2 to 2.8 , with anion deficits of 39-195 $\mu \mathrm{eq} / \mathrm{L}$, translating into anionic charge per DOC mass ranging from 2.8 to $10.2 \mu \mathrm{eq} / \mathrm{mg}$ DOC, with an average of $5.7 \mu \mathrm{eq} / \mathrm{mg}$ DOC. In the Larry River catchment samples, $\mathrm{Na}^{+}$was the dominant cation (average $38 \%$ ), followed by $\mathrm{Ca}^{2+}(22 \%)$ and $\mathrm{H}^{+}(19 \%)$. DOC dominated the anions (estimated as an average of $49 \%$ ) followed by $\mathrm{Cl}^{-}(46 \%)$ and $\mathrm{SO}_{4}^{2-}(5 \%)$.

Titration of the samples with dilute alkali and interpretation of the results using the technique discussed by Lee [1980] revealed no strong evidence for the presence of more than one acid (L2, L3 27/3 and M5), as shown by variations in the gradient of the $\mathrm{m}=\left[\mathrm{H}^{+}\right] /\left[\mathrm{OH}^{-}\right]_{\text {add }}$ derivative plotted against $p \mathrm{H}$ of the solution. The other three samples did show evidence for more than one acid. The dissociation constant $\left(p \mathrm{~K}_{\mathrm{a}}\right)$ values of the dominant acids ranged from 3.97 to 5.14, with an average of 4.69 .

\section{Discussion}

Jackson [1987] described the hydrological changes associated with the drainage and planting of these wetland terraces. In the undisturbed L2 catchment, the soil remains saturated for much of the year, with the water table rising rapidly during rainfall events and falling slowly during dry periods. Quick flow contributes about $70 \%$ of the total runoff. In the disturbed L3 catchment, the soils on the ridges rapidly become unsaturated after the rainfall has ceased, with soil water pressure potentials greater than -30 mbar. Within individual events, the quickflow runoff was $0-30 \%$ greater in catchments $\mathrm{L} 1$ and L3 than in undisturbed catchment L2, and stream discharge was more responsive to small precipitation events $(<10 \mathrm{~mm})$. With disturbance, there was an increased frequency of peak flows $\left(>10 \mathrm{~L} \mathrm{~s}^{-1} \mathrm{ha}^{-1}\right)$ and lower base flows $\left(<0.05 \mathrm{~L} \mathrm{~s}^{-1} \mathrm{ha}^{-1}\right)$. Sediment trapped in the weir increased from 0.1 to $0.3 \mathrm{~m}^{3} \mathrm{ha}^{-1} \mathrm{yr}^{-1}$ before disturbance to up to $3.5 \mathrm{~m}^{3} \mathrm{ha}^{-1} \mathrm{yr}^{-1}$ after disturbance and there was also increased erosion of the stream channel downstream of the disturbed catchment weirs.

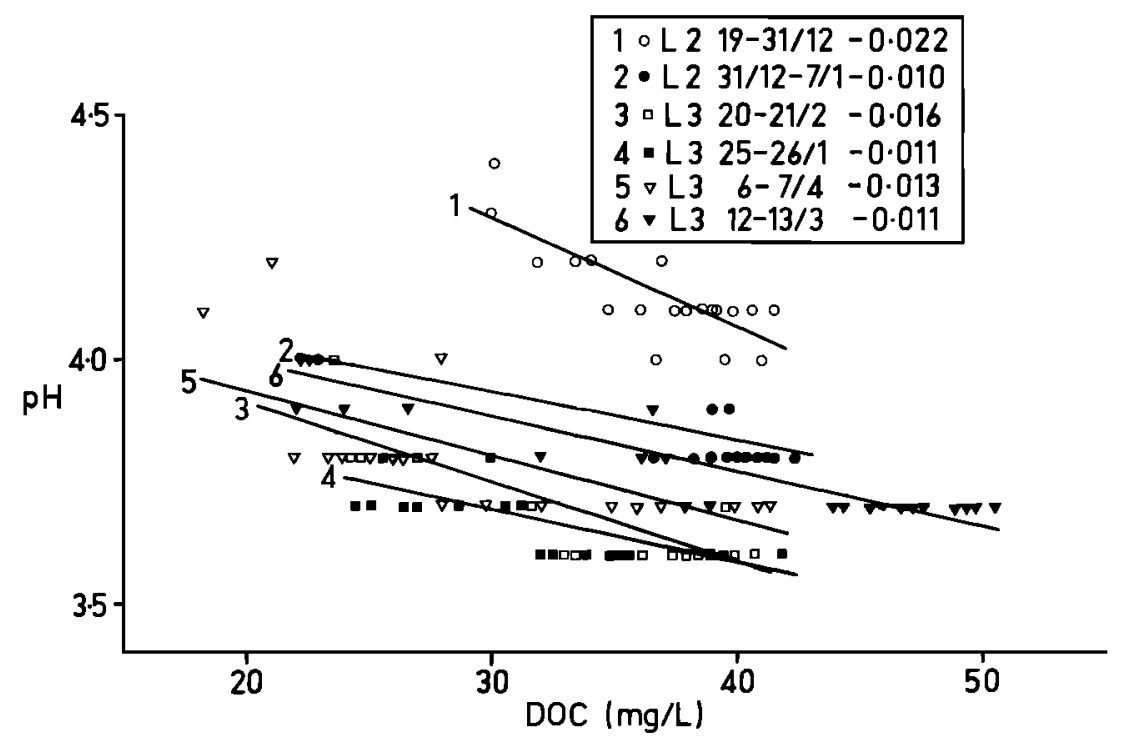

Fig. 5. The relationship between $p \mathrm{H}$ and DOC concentration in stream water during storms in catchments L2 and L3. The numbers refer to the date of collection (day and month in 1986) and the regression coefficient for the regression lines. 
TABLE 5. Chemical Composition of Six Stream Water Samples From the Larry River (L1, L2, and L3) and Maimai (M5 and M6) Catchments

\begin{tabular}{|c|c|c|c|c|c|c|c|c|c|c|c|c|c|c|c|}
\hline Sample & $p \mathrm{H}$ & $\mathrm{H}^{+}$ & $\mathrm{Ca}^{2+}$ & $\mathrm{Mg}^{2+}$ & $\mathbf{K}^{+}$ & $\mathrm{Na}^{+}$ & $\mathrm{NH}_{4}^{+}$ & $\mathrm{NO}_{3}^{-}$ & $\mathrm{Cl}^{-}$ & $\mathrm{SO}_{4}^{2-}$ & $\begin{array}{l}\text { Cation: } \\
\text { Anion } \\
\text { Ratio }\end{array}$ & $\begin{array}{l}\text { Anion } \\
\text { Deficit, } \\
\mu e q / L\end{array}$ & $\begin{array}{l}\mathrm{DOC}, \\
\mathrm{mg} / \mathrm{L}\end{array}$ & $\begin{array}{l}\text { Anion } \\
\text { Deficit } \\
\text { Ratio, } \\
\text { meq/g } \\
\text { DOC }\end{array}$ & $p \mathrm{~K}_{\mathrm{a}}$ \\
\hline L1 April 9 & 4.3 & 52 & 73.0 & 40.0 & 3.8 & 129.6 & 4.7 & 0.3 & 100.6 & 6.3 & 2.83 & 195.9 & 39.4 & 5.0 & $\begin{array}{c}4.40 \\
(3.97)\end{array}$ \\
\hline $\begin{array}{l}\text { L2 April } 9 \\
\text { L3 April } 9\end{array}$ & $\begin{array}{l}4.0 \\
4.3\end{array}$ & $\begin{array}{r}118 \\
56\end{array}$ & $\begin{array}{l}53.5 \\
60.5\end{array}$ & $\begin{array}{l}28.3 \\
61.7\end{array}$ & $\begin{array}{r}5.9 \\
28.5\end{array}$ & $\begin{array}{r}82.6 \\
127.4\end{array}$ & $\begin{array}{r}17.6 \\
3.4\end{array}$ & $\begin{array}{l}0.4 \\
3.2\end{array}$ & $\begin{array}{l}126.3 \\
137.2\end{array}$ & $\begin{array}{r}4.2 \\
31.3\end{array}$ & $\begin{array}{l}2.34 \\
1.97\end{array}$ & $\begin{array}{l}175.0 \\
165.8\end{array}$ & $\begin{array}{l}41.7 \\
37.4\end{array}$ & $\begin{array}{l}4.2 \\
4.4\end{array}$ & $\begin{array}{c}4.59 \\
4.44 \\
(4.40)\end{array}$ \\
\hline $\begin{array}{l}\text { L3 March } 27 \\
\text { M5 April } 9 \\
\text { M6 April } 9\end{array}$ & $\begin{array}{l}5.1 \\
5.6 \\
5.5\end{array}$ & $\begin{array}{l}8.3 \\
2.4 \\
3.1\end{array}$ & $\begin{array}{l}71.5 \\
76.5 \\
32.0\end{array}$ & $\begin{array}{l}31.7 \\
43.3 \\
25.8\end{array}$ & $\begin{array}{r}18.5 \\
28.2 \\
9.2\end{array}$ & $\begin{array}{l}106.5 \\
120.4 \\
140.4\end{array}$ & $\begin{array}{l}1.2 \\
5.1 \\
0.1\end{array}$ & $\begin{array}{l}0.7 \\
2.9 \\
0.2\end{array}$ & $\begin{array}{l}161.4 \\
102.2 \\
161.4\end{array}$ & $\begin{array}{l}20.8 \\
12.5 \\
10.4\end{array}$ & $\begin{array}{l}1.30 \\
2.35 \\
1.22\end{array}$ & $\begin{array}{r}54.8 \\
158.3 \\
38.6\end{array}$ & $\begin{array}{r}19.7 \\
15.6 \\
5.3\end{array}$ & $\begin{array}{r}2.8 \\
10.2 \\
7.3\end{array}$ & $\begin{array}{c}4.71 \\
4.85 \\
4.72 \\
(5.14)\end{array}$ \\
\hline
\end{tabular}

Figures in parentheses beneath $p \mathrm{~K}_{\mathrm{a}}$ indicate presence of secondary acids of the acid dissociation constants shown.

\section{DOC Flux in Larry River Catchments}

The sources of DOC in the Larry River undisturbed catchment are very similar to those in the nearby Maimai catchments: notably, throughfall, stemflow, and the soil organic matter [Moore, 1989]. The high concentrations of DOC in stemflow and throughfall are probably associated with the occurrence of scale insects (Eriococcus ovariensis) causing manuka blight, which produce sap sugars containing honey dew [Zondag, 1977]. In the catchments planted with pine, Collier [1988] has shown that pine stemflow and throughfall concentrations of DOC are lower (7.9 and 6.5 $\mathrm{mg} / \mathrm{L}$ ) than that of manuka.

However, DOC export from the undisturbed L2 catchment in 1986 was much higher $\left(42 \mathrm{~g} \mathrm{~m}^{-2} \mathrm{yr}^{-1}\right)$ than from the undisturbed M6 and M15 catchments at Maimai $\left(9 \mathrm{~g} \mathrm{~m}^{-2}\right.$ $\left.\mathrm{yr}^{-1}\right)$. Discharge-weighted DOC concentrations at L2 are 38 $\mathrm{mg} / \mathrm{L}$, compared to $6 \mathrm{mg} / \mathrm{L}$ at the two Maimai catchments. There appear to be two main reasons for this difference in DOC export. First, because subsoils in the Larry River catchments are unable to adsorb DOC, high concentrations pass through into the drainage waters. Second, the saturated conditions for much of the year in the Larry River catchment mean that water moves across the soil surface or through the organic surface horizons. These conditions also probably account for the high DOC concentrations $(10-45 \mathrm{mg} / \mathrm{L})$ reported in other wetland streams [e.g., Brinson et al., 1980; Kerekes et al., 1986; McKnight et al., 1985; Moore, 1987a, b, c; Naiman, 1982; Mulholland, 1981; Mulholland and Kuenzler, 1979; Schlesinger and Melack, 1981]. DOC concentrations are also high in the black water rivers of the southeastern United States, which are underlain by strongly weathered, sandy soils and which have a large floodplain area covered by rich forests [Meyer, 1986].

\section{Regulation of DOC Concentrations in Larry River Streams}

The pattern between DOC and discharge in the Larry River catchments is more complex than the simple positive association observed in the Maimai catchments [Moore, this issue]. The general decline in DOC concentration with increasing discharge, observed in catchments L1 and L3, has also been noted by Collier [1988], who also found that streams in catchments in L1 and L2 did not exhibit a strong correlation between DOC and discharge at low flows. The well-developed hysteresis in the DOC:discharge relationship within storms in catchment L3 reduces the strength of the overall DOC:discharge relationship. These patterns can be explained by differences in the pathways that precipitation takes to the stream. In the undisturbed catchment, no distinct pattern has developed, perhaps because of the slow movement of water to the stream and the mixing of precipitation, throughfall, stemflow, and soil water components. In catchment L3, the pattern is most strongly developed because of the exposure of the impervious subsoils and the deep, permeable, disturbed peaty soils on the ridges.

A negative correlation between discharge and DOC has been found in several other wetland catchments [e.g., Clair and Freedman, 1986; Freedman and Clair, 1987; Naiman, 1982]. Mulholland [1981] reported a negative correlation between seasonal DOC concentration and seasonal discharge in a swamp catchment, but that DOC concentrations increased with increasing stream flow during storms.

Disturbance had a relatively minor effect on stream DOC export in the Larry River catchments. In the year after disturbance, DOC export showed a slight increase, mainly because of the higher runoff and lower DOC concentrations at peak flows. The lower estimated DOC export recorded in the L1 catchment 4 years after disturbance may reflect lowered DOC production from decomposing peaty soils and the weak development of the vegetation cover. Moore [1987b] observed little change in DOC concentrations associated with the drainage and harvesting of ombrotrophic peatlands in Quebec.

\section{Streamwater Acidity}

The study at the Larry River catchments has shown the importance of DOC in stream water acidity. The large anion deficit and the high anion deficit:DOC ratio (average of 5.7 $\mu \mathrm{eq} / \mathrm{mg}$ ) is in close agreement with the deficits and ratios reported by Cronan and Aiken [1985], Dempsey and O'Melia [1983], Eshleman and Hemond [1985], Gorham et al. [1985], Henriksen and Seip [1980], and Kerekes et al. [1986] which range from 4 to $10 \mu \mathrm{eq} / \mathrm{mg}$. The flux of moderately strong acidity (using the average value of $6 \mathrm{meq} / \mathrm{g} \mathrm{DOC}$ ) from the Larry River catchments can be estimated to be in the range of 184 to $263 \mathrm{meq} \mathrm{m}^{-2} \mathrm{yr}^{-1}$. This export of acidity is about 6 times greater than that reported for Thoreau's bog [ $\mathrm{Mc}$ Knight et al., 1985] and Provencial Brook [Eshleman and Hemond, 1985]. 
Dissociation constants for the dominantly organic acids in the Larry River water samples ( $\left.p \mathrm{~K}_{\mathrm{a}} 4.4-4.9\right)$ fall into the upper part of the range (3.2-5.0) established for soil and water humic substances by Cronan and Aiken [1985], Dempsey and O'Melia [1983], Eshleman and Hemond [1985], and Sposito et al. [1977]. One reason for the higher $p \mathrm{~K}_{\mathrm{a}}$ values in the Larry River streams may be that there is little evidence of deposition of strong mineral acids (e.g., sulfuric acid) in precipitation, which occurred in many other studies [e.g., Cronan and Aiken, 1985; Eshleman and Hemond, 1985; Freedman and Clair, 1987]. In organic-rich streams in the northern hemisphere, the observed acidity is a function of both organic and inorganic acids, with the contribution varying with season [e.g., Gorham et al., 1986; Kerekes et al., 1986].

\section{Conclusions}

The studies of the Maimai [Moore, this issue] and Larry River forested catchments have shown that the main sources of DOC are throughfall, stemflow, and decomposing litter and soil organic matter and that the magnitude of these sources is similar. The export of DOC from the catchments is controlled partly by the ability of the soils and the stream channel to act as a sink for DOC and partly by the pathways taken by water to reach the stream.

Catchment disturbance can affect DOC concentrations in streams and DOC export, through changes in the sources of DOC, the movement of water and the channel characteristics. In the upland Maimai catchments, clear-cutting has produced a significant increase in stream DOC concentrations and DOC export 8-10 years after the disturbance. Management practices within the clear-cut catchments affect DOC, mainly through organic debris left in and around the stream channel. In the wetland Larry River catchments, drainage and forest removal had little immediate effect on stream DOC concentrations and DOC export, but lead to a decrease in both parameters after 4 years. Thus there are no overall responses in DOC flux to disturbance, but each set of catchments will respond to changes in the sources and sinks of DOC and hydrologic pathways. DOC can influence water acidity where DOC concentrations are high and soils are acid and low in base cations.

Acknowledgments. The authors gratefully acknowledge the support and encouragement of the New Zealand Forest Research, Christchurch, and its staff, especially J. Gray, S. Kitchingman, A. J. Pearce, and L. K. Rowe. H. J. K. Powell of the Department of Chemistry, University of Canterbury provided advice and facilities for the titration analyses. K. J. Collier measured DOC concentrations on some samples and made extremely useful comments on a draft. The Department of Geography, University of Canterbury, provided a very hospitable environment for a sabbatical leave. Partial financial support was provided by the Natual Sciences and Engineering Research Council of Canada, through Operating and Travel Grants.

\section{REFERENCES}

Aldridge, R., and R. J. Jackson, Interception of rainfall by manuka (Leptospermum scoparium) at Taita, New Zealand, N. Z. J. Sci., II, 301-317, 1968

Brinson, M. M., H. D. Bradshaw, R. N. Holmes, and J. B. Elkins, Litterfall, stemflow, and throughfall nutrient fluxes in an alluvial forest swamp, Ecology, 61, 827-835, 1980.

Clair, T. A., and B. Freedman, Patterns and importance of dissolved organic carbon in four acidic brownwater streams in Nova Scotia, Canada, Water Air Soil Pollut., 31, 139-147, 1986.
Collier, K. J., Ecology of acid brownwater streams in Westland, New Zealand, Ph.D. thesis, 252 pp., Univ. of Canterbury, New Zealand, 1988.

Cronan, C. S., and G. R. Aiken, Chemistry and transport of soluble humic substances in forested watersheds of the Adirondack Park, New York, Geochim. Cosmochim. Acta, 49, 1697-1705, 1985.

Dann, M. S., J. A. Lynch, and E. S. Corbett, Comparison of methods for estimating sulfate export from a forested watershed, J. Environ. Qual., 15, 140-145, 1986.

Davies-Colley, R. J., and W. N. Vant, Absorption of light by yellow substance in freshwater lakes, Limnol. Oceanogr., 32, 416-425, 1987.

Dempsey, B. A., and C. R. O'Melia, Proton and calcium complexation of four fulvic acid fractions, in Aquatic and Terrestrial Humic Substances, edited by R. F. Christman and E. T. Gjessing, pp. 239-274, Butterworth, Stoneham, Mass., 1983.

Eshleman, K. N., and H. F. Hemond, The role of soluble organics in the acid-base status of surface waters at Bickford Watershed, Massachusetts, Water Resour. Res., 21, 1503-1510, 1985.

Foster, I. D. L., and I. C. Grieve, Short-term fluctuations in dissolved organic matter concentrations in streamflow draining a forested watershed and their relationship to the catchment budget, Earth Surf. Processes Landforms, 7, 417-425, 1982.

Freedman, B., and T. A. Clair, Ion mass balances and seasonal fluxes from four acidic brownwater streams in Nova Scotia, Can. J. Fish. Aquat. Sci., 44, 538-548, 1987.

Gjessing, E. T., Physical and Chemical Characteristics of Aquatic Humus, Butterworth, Stoneham, Mass., 1976.

Gorham, E., S. J. Eisenreich, J. Ford, and M. V. Santelman, The chemistry of bog waters, in Chemical Processes in Lakes, edited by W. Stumm, pp. 339-363, John Wiley, New York, 1985.

Gorham, E., J. K. Underwood, F. B. Martin, and J. G. Ogden III, Natural and anthropogenic causes of lake acidification in Nova Scotia, Nature, 324, 451-453, 1986.

Henriksen, A., and H. M. Seip, Strong and weak acids in surface waters of southern Norway and southwestern Scotland, Water Res., 14, 809-813, 1980.

Hobbie, J. E., and G. E. Likens, Output of phosphorus, dissolved organic carbon, and fine particulate carbon from Hubbard Brook watersheds, Limnol. Oceanogr., 18, 734-742, 1973.

Jackson, R. J., Investigation of the properties and genesis of West Coast wet land soils, South Island, New Zealand, 5, Physical characteristics of soil profiles and soil water regimes, $N$. Z. J. Sci.. 27, 155-174, 1984.

Jackson, R. J., Hydrology of an acid wetland before and after draining for afforestation, western New Zealand, Forest Hydrology and Watershed Management (Proceedings of the Vancouver Symposium), IAHS Publ. 167, pp. 465-474, Gentbrugge, Belgium, 1987.

Kerekes, J., S. Beauchamp, R. Tordon, C. Tremblay, and T. Pollock, Organic versus anthropogenic acidity in tributaries of the Kejimkujik watersheds in western Nova Scotıa, Water Air Soil Pollut., 3I, 165-173, 1986.

Lee, Y. H., The linear plot: A new way of interpreting titration data, used in determination of weak acids in lake water, Water Air Soil Pollut., 14, 287-298, 1980.

McKnight, D. M., E. M. Thurman, R. L. Wershaw, and H. Hemond, Biogeochemistry of aquatic humic substances in Thoreau's Bog, Concord, Massachusetts, Ecology, 66, 1339-1352, 1985.

Mew, G., Application of the term "pakihi" in New Zealand-A review, J. R. Soc. N. Z., 13, 175-198, 1983.

Mew, G., and R. Lee, Investigation of the properties and genesis of West Coast wetland soils, South Island, New Zealand, 1, Type localities, profile morphology, and soil chemistry, N.Z. J. Sci., $24,1-24,1981$.

Mew, G., and R. Lee, The genesis and classification of soils on wet terraces and moraines in New Zealand, J. Soil Sci., 39, 125-138, 1988.

Meyer, J. L., Dissolved organic carbon dynamics in two subtropical blackwater rivers, Arch. Hydrobiol., 108, 119-134, 1986.

Meyer, J. L., and C. M. Tate, The effects of watershed disturbance on dissolved organic carbon dynamics of a stream, Ecology, 64 33-44, 1983.

Moore, T. R., Patterns of dissolved organic matter in subarctic 
peatlands, eastern Canada, Earth Surf. Processes Landforms, 12, 387-397, 1987a.

Moore, T. R., A preliminary study of the effects of drainage and harvesting on water quality in ombrotrophic bogs near Sept-Iles, Quebec, Water Resour. Bull., 23, 785-791, 1987b.

Moore, T. R., Dissolved iron and organic carbon in northern peatlands, Soil Sci., 145, 70-76, 1987c.

Moore, T. R., An assessment of a simple spectrophotometric method for the determination of dissolved organic carbon in freshwaters, N. Z. J. Mar. Freshw. Res., 21, 585-589, 1987d.

Moore, T. R., Dynamics of dissolved organic carbon in forested and disturbed catchments, Westland, New Zealand, 1, Maimai, Water Resour. Res., this issue.

Mulholland, P. J., Organic carbon flow in a swamp-stream ecosystem, Ecol. Monogr., 51, 307-322, 1981.

Mulholland, P. J., and E. J. Kuenzler, Organic carbon export from upland and forested wetland watersheds, Limnol. Oceanogr., 24, 960-966, 1979.

Naiman, R. J., Characteristics of sediment and organic carbon export from pristine boreal forest watersheds, Can. J. Fish. Aquat. Sci., 39, 1699-1718, 1982.

Oliver, B. G., E. M. Thurman, and R. L. Malcolm, The contribution of humic substances to the acidity of colored natural waters, Geochim. Cosmochim. Acta, 47, 2031-2035, 1983.

Reuter, J. H., and E. M. Perdue, Importance of heavy metal organic matter interactions in natural waters, Geochem. Cosmochim. Acta , 41, 325-334, 1977.

Ross, C. W., G. Mew, and P. L. Searle, Soil sequences on two terrace systems in the North Westland area, New Zealand, N. Z. J. Sci., 20, 231-244, 1977.

Schlesinger, W. H., and J. M. Melack, Transport of organic carbon in the world's rivers, Tellus, 33, 172-187, 1981.

Searle, P. L., Automated colorimetric determination of ammonium ions in soil extracts with Technicon Autoanalyzer II equipment, N. Z. J. Agric. Res., 18, 183-187, 1975.

Sposito, G., K. M. Holtzclaw, and D. A. Keech, Proton binding in fulvic acid extracted from sewage sludge-soil mixtures, Soil $\boldsymbol{S} c i$. Soc. Am. J., 4I, 1119-1125, 1977.

Tate, C. M., and J. L. Meyer, The influence of hydrologic conditions and successional state on dissolved organic carbon export from forested watersheds, Ecology, 64, 25-32, 1983.

Thurman, E. M., Organic Geochemistry of Natural Waters, M. Nijhoff/W. Junk Publishers, Boston, Mass., 1985.

Zondag, R., Eriococcus orariensis Hoy, Causal agent of manuka blight, Forest and Timber Insects in New Zealand, Rep. 23, N. Z. For. Serv., Wellington, New Zealand, 1977.

R. J. Jackson, Forest Research Institute, Ministry of Forestry, P.O. Box 31-011, Christchurch, New Zealand.

T. R. Moore, Department of Geography, McGill University, 805 Sherbrooke Street West, Montreal, Quebec, Canada H3A 2K6.

(Received May 9, 1988;

revised January 23, 1989; accepted February 8, 1989.) 